\title{
From Data Sources to Information Sharing in SME Collaborative Networks Supporting Internationalization: A Socio-Semantic Approach
}

\author{
Eric Costa ${ }^{1,2(\bowtie)}$, António Lucas Soares ${ }^{1,2}$, \\ and Jorge Pinho de Sousa ${ }^{1,2}$ \\ 1 INESC TEC - INESC Technology and Science, \\ Campus da FEUP, Rua Dr. Roberto Frias 378, 4200-465 Porto, Portugal \\ \{eric.m.costa,jsousa\}@inesctec.pt, als@fe.up.pt \\ ${ }^{2}$ FEUP - Faculty of Engineering, University of Porto, \\ Rua Dr. Roberto Frias S/N, 4200-465 Porto, Portugal
}

\begin{abstract}
Information is a crucial asset to successful internationalization, as it allows to reduce risks and uncertainty and to facilitate international expansion. Information about foreign markets and activities can be obtained by companies from internal or external sources, and in formal or informal ways. Industrial business associations (IBAs) are one of the external information sources. Due to their resource constraints, small and medium enterprises (SMEs) tend to highly depend on the services and information of IBAs to expand their business overseas. However, to improve their role in supporting SME internationalization, one important development is for IBAs to evolve towards more collaborative networks, by sharing more organized and valued information with their associates, but also by fostering information flows and more collaborations between them. This paper contributes to this view by synthetizing current data and information sources to support SME internationalization, based on a literature review, on interviews with Portuguese IBAs, and on expert opinion. An innovative aspect is to present a first instantiation of a socio-semantic model, opening paths for further developments in this area, and contributing to the community of Collaborative Networks.
\end{abstract}

Keywords: Data and information sources - Internationalization of SMEs • International business - Business associations · Collaborative networks · Socio-semantic approach

\section{Introduction}

Today, in a Big Data era and information overload, the ability of companies to extract vital information from the vast amount of available data sources represents one of the main key success factors for achieving competitive advantage [1]. Thus, in this data-rich world, having access to valued information is also a crucial asset for companies to remain successful in international markets [2]. Internationalization requires high quality information extracted from a variety of different data sources but the 
problem is that many small and medium enterprises (SMEs) still face major challenges to have access and to manage internationalization-related information and knowledge, to reach more effective international endeavors [3]. Therefore, having more support from external entities and having access to credible information sources is a fundamental aspect for SMEs to improve their international operations.

Although existing different opinions about the utility of their services, industrial business associations (IBAs) are institutional actors that provide some support to SME internationalization, who are also identified in previous studies as one source of information about international trade activities $[4,5]$. Nevertheless, previous research also points that the IBAs' role as information providers and as external support to internationalization may be improved by progressing to a collaborative network, by sharing more organized and valued information, and by promoting flows of information and knowledge, and more collaborations among their associate companies [6-8].

Therefore, this paper presents one important step for contributing to this view, by identifying, characterizing, and synthetizing current data and information sources to support SME internationalization. These findings allow to make a contribution for improving the first stage of the information management life-cycle of IBAs, which is the information acquisition stage [9]. Other stages of the information management life-cycle (information organization, storing, distribution, and use) will be explored in future developments of this study.

\section{Research Methodology}

The research methodology of this study was composed by four parts: (i) an exploratory literature review; (ii) interviews with IBAs; (iii) the use of expert opinion; (iv) the adoption of a socio-semantic approach.

A literature review was first performed to synthetize the data and information sources indicated in previous studies that are used by companies in their internationalization processes (Sect. 3.1). After that, one of the information sources was explored in more detail, i.e. the IBAs (Sect. 3.2.).

To increase the knowledge about this specific context of IBAs, an empirical study was performed by collecting data through interviews with 20 IBAs in Portugal (Sect. 4). This part of the study helped to reinforce the practical relevance of the research, as well as to identify specific information sources that IBAs use to support the international activities of their associate SMEs.

In addition to that, expert opinion was also used, by contacting people with knowledge on existing information sources for internationalization, allowing to discover additional sources (Sect. 5).

Finally, the socio-semantic approach of Pereira et al. [10, 11] was adopted in this paper to present the first instantiation of a socio-semantic model of a collaborative network for internationalization (Sect. 6). This approach was adopted as it allows to obtain a more socio-cognitive perspective to create more effective tools that can better represent the complexity of information and knowledge sharing in collaborative networks of organizations [10]. Therefore, in this approach, organizational networks are modelled as socio-semantic networks. A socio-semantic network is then a network of 
relationships between the organizational actors (individuals and groups of the organizations that form the collaborative network) and the concept structures (concepts and conceptual structures organized in business domains) [11]. At the end, it is possible to obtain a socio-semantic network model composed by three networks: (i) the social network (links between individuals); (ii) the semantic network (links between concepts); and (iii) the socio-semantic network (links individuals to concepts). As stated by Pereira et al. [10, 11], this integrated view can help researchers that are studying collaborative networks to better understand the interplay between knowledge structures and social structures.

\section{Literature Review Findings}

\subsection{Information Sources for International Business}

A systematic search and acquisition of information about foreign markets and foreign partners has been considered, in the International Business (IB) literature, as one of the most critical factors for achieving the internationalization success [12]. Theodosiou and Katsikea [13] consider that the export/internationalization information system comprises four key dimensions: information sources, information acquisition, information dissemination, and information utilization. In this paper, we are specifically concerned about the information sources.

Quality and relevant information is required to compensate the lack of prior knowledge and experience in foreign markets, and as a way to reduce internationalization uncertainties [14]. Therefore, companies tend to rely on multiple sources of information to satisfy their internationalization needs [3, 13]. These information sources can be classified in different ways $[4,15]$ :

- Primary and secondary sources;

- Formal and informal sources;

- Internal and external sources.

Information can be collected from primary sources, based on specific actions developed by the own company, such as market studies, or can come from secondary sources that has been already collected by other entities, such as statistics from governments. Information can be derived from formal sources, where data is acquired through formal actions, such as meetings and focus group discussions, or from more informal sources, when the information is obtained by personal and casual interactions with partners. Information can also be acquired from internal company sources, based on previous experiences in international markets and by using internally stored information, such as financial accounts. Finally, companies can also rely on information from sources external to the organization, by using the experience of others and externally available information.

There are many ways for a firm to acquire information and knowledge about foreign markets [12]. Xie and Amine [14] found that decision-makers typically choose their information sources as a function of their perceived utility. Nonetheless, it has been shown in previous studies that different information sources are not equally useful 
for the internationalization process [13]. The use of information sources depends on many factors, among which the size of a company, and the advancement and level of experience regarding its international activity, are some of the most important to have in consideration [16]. For example, previous studies agree that SMEs tend to use less expensive, easily accessible, and more informal sources when compared to large companies $[17,18]$. From other side, large companies rely more on primary sources, by conducting their own studies and market analyzes [16].

Due to the existence of a large variety of classifications of information sources in the literature, we summarize the information by cross-casing the analyzed literature and create our own classification (Table 1).

Table 1. Data and information sources for internationalization from the literature, according to location

\begin{tabular}{|c|c|}
\hline Information sources & References \\
\hline \multicolumn{2}{|l|}{ Internal sources } \\
\hline $\begin{array}{l}\text { Personal contacts (e.g. export customers, own agents and } \\
\text { distributors) }\end{array}$ & {$[2,4,5,13,17,19-22]$} \\
\hline Company's own knowledge and experience & {$[5,16,22]$} \\
\hline Company's sales people and offices, and export agents & {$[4,13,16-21]$} \\
\hline Foreign market visits & {$[4,12,13,17,19,20,22]$} \\
\hline Company's studies and market research & {$[2,4,16,17,19,21]$} \\
\hline $\begin{array}{l}\text { Company's records (e.g. reports from sales people, } \\
\text { statistical reports, trade contracts and invoices) }\end{array}$ & {$[4,16-19,22,23]$} \\
\hline \multicolumn{2}{|l|}{ External sources } \\
\hline \multicolumn{2}{|l|}{ Business networks } \\
\hline Suppliers & {$[4,5,17,19,22,23]$} \\
\hline Competitors & {$[16,17,22]$} \\
\hline Customers & {$[4,5,16-19,22,23]$} \\
\hline Strategic partners and other organizations in the industry & {$[4,20,22]$} \\
\hline Overseas agents, distributors and representatives & {$[4,5,16-19,23]$} \\
\hline Commercial brokers and freight forwarders & {$[4,17,19,20,22]$} \\
\hline \multicolumn{2}{|l|}{ Social networks } \\
\hline Friends & {$[5,14]$} \\
\hline Family & {$[5,14]$} \\
\hline \multicolumn{2}{|l|}{ Institutional networks } \\
\hline Government offices/ministries & {$[2,4,13,17,19-21]$} \\
\hline Embassies & {$[4,13,16-20]$} \\
\hline Chambers of commerce & {$[4,13,16,17,19,21,22]$} \\
\hline Business, trade and industry associations & {$[2,4,5,13,17-21]$} \\
\hline Export agencies & {$[2,4,5,12,13,16,17,19,22]$} \\
\hline Consulting and research agencies and institutes & {$[2,4,12,13,16-18,20-22]$} \\
\hline Universities and polytechnics & {$[2,17]$} \\
\hline
\end{tabular}


Table 1. (continued)

\begin{tabular}{l|l}
\hline Information sources & References \\
\hline Banks & {$[4,16,17,19-22]$} \\
\hline $\begin{array}{l}\text { Physical documents and publications } \\
\text { Trade catalogues, journals, magazines, and books }\end{array}$ & {$[4,13,16-19,21,22]$} \\
\hline $\begin{array}{l}\text { Local and international periodicals, journals and } \\
\text { newspapers }\end{array}$ & {$[4,13,17-22]$} \\
\hline $\begin{array}{l}\text { Internet (e.g. trade lists, statistics, ratings and rankings, } \\
\text { on-line market studies and surveys, on-line journals and } \\
\text { newspapers, clients and customers' webpages) }\end{array}$ & {$[2,12,13,16,22,23]$} \\
\hline $\begin{array}{l}\text { Databases, directories and repositories } \\
\text { Public and commercial libraries }\end{array}$ & {$[4,16-18]$} \\
\hline $\begin{array}{l}\text { Trade missions, trade fairs/exhibitions and other } \\
\text { export/promotion programs }\end{array}$ & {$[2,4,17,19]$} \\
\hline
\end{tabular}

\subsection{Business Associations as Information Sharers}

Looking at the diversity of entities and organizations that act as information sources to support internationalization processes of companies (Table 1), chambers of commerce and IBAs are many times referred as one of those institutional entities of support. These entities represent different firms of a specific industrial sector or act as intermediaries within a multi-sectoral network of companies [7]. Therefore, they are characterized by their collective and member-based nature, where members share a common interest and membership is most of the times voluntary [24, 25]. In addition to that, they are intermediaries between business sectors and government action, and they provide services for their members [25, 26].

Many empirical studies have been made to study the information source behavior of exporting SMEs and large companies, in order to understand the most used information sources in internationalization processes. Regarding the usefulness of the information provided by IBAs, there are mixed opinions about that. By performing an integrative review of the literature, Leonidou and Theodosiou [4] conclude that although the experience of chambers of commerce and trade associations offer first-hand information about foreign markets, this information was not extensively used nor regarded as useful by companies. Looking at other specific empirical studies, Benito et al. [18] report the results of a survey with 221 Norwegian exporting companies, revealing that large companies, in contrast to smaller ones, generally give higher priority to the information of industry associations rather that the information that is provided by the export council. In a more qualitative fashion, Walters [20, 21] performs a first study with 33 companies from the USA and a second one, with the same sample size, but focusing in Norway. In both studies, industry associations are considered by companies as a useful information source to have access to more general, cheap and easy to acquire information about markets and exports (e.g. exports/imports, trade barriers), and to obtain contacts in foreign markets. However, companies also consider that more expensive information sources, with more detailed and market 
related experience, can be more helpful for their international expansion. The counterpart of using this kind of sources is the intrinsic costs that will limit their use.

By analyzing the information source behavior of 80 export firms in Cyprus, Leonidou and Katsikea [17] demonstrate that companies tend to rely more on personal contacts rather than impersonal sources, such as chambers of commerce and industry associations, when gathering information for internationalization. In fact, the analyzed companies, from one side, recognize the existence of information services from those institutional entities but, from the other side, they often consider to be information of low value. In contrast, Riddle and Gillespie [5] measure the company owners' awareness of the role of two business associations that act as information sources for SMEs in the Turkish clothing export industry. Results show that these business associations are perceived as very important information sources for companies' exports, mainly to have access to information about the export laws, foreign markets and the export process. More recent studies show that business associations and chambers of commerce are perceived to be the most important institutional information sources for Polish exporters [16, 22]. Gashi et al. [27] and Patel-Campillo and DeLessio-Parson [28] suggest a positive influence of membership in business associations to the propensity of SMEs to export. Finally, findings of Costa et al. [7] show that, although recognized by some Portuguese companies as a useful source of information, their information management role can be improved to better meet their internationalization needs.

In summary, previous literature shows that business associations and chambers of commerce have the potential to be important information sources to support internationalization processes, mainly for SMEs. However, as stated by Costa et al. [6, 7], these institutional actors might have a more active role as information managers and in fostering collaboration between associates. The next section starts to contribute to these aspects by identifying and characterizing current internal and external information sources that are used by IBAs to support SME internationalization.

\section{Insights from Industrial Business Associations}

Results from the interviews show that Portuguese IBAs use different data and information sources to provide information to support the internationalization of their members. Compared to the information sources found in the literature (Table 1), the ones used by IBAs are, in general, similar. Nonetheless, some other specific internal and external information sources are identified in this section, as well as some particular websites and cooperative entities. The findings allow to add new elements to the list of available information sources useful for internationalization.

According to the interviewees, the use of information sources for internationalization processes is very flexible and different from case to case. The information can be acquired for obtaining more macro-economic views of industrial sectors and countries, or can be more detailed, by using information sources to share specific information about promotional actions or internationalization opportunities. Most of the IBAs also 
have a large diversity of members and sub-sectors in the same industrial sector, making it difficult to obtain information to satisfy the specific needs of each company. Naturally, this situation complicates the process of synthetizing all the information sources used by IBAs, but an attempt to achieve this is presented in Table 2.

The IBAs' network of contacts is referred as one of the most important information source. Most of them have many established and trusted contacts that comes from decades of experience, acquired in previous studies and internationalization projects. So the own experience and know-how is a vital information source for the IBAs. A particular case to highlight here is the specific IBAs' members that often serve as a

Table 2. Data and information sources used by IBAs to support SME internationalization

\begin{tabular}{|c|c|c|}
\hline $\begin{array}{l}\text { Type of } \\
\text { source }\end{array}$ & Category & Information source \\
\hline \multirow{12}{*}{$\begin{array}{l}\text { Internal } \\
\text { sources }\end{array}$} & \multirow{4}{*}{$\begin{array}{l}\text { Own experience } \\
\text { and know-how }\end{array}$} & Previous market studies and industrial sector studies \\
\hline & & Previous internationalization projects \\
\hline & & Previous promotional activities \\
\hline & & $\begin{array}{l}\text { Previous international experiences and visits to foreign } \\
\text { countries }\end{array}$ \\
\hline & \multirow[t]{2}{*}{ Contacts } & Network of contacts with different entities \\
\hline & & Associates (members) \\
\hline & \multirow[t]{2}{*}{ Human resources } & Export agents \\
\hline & & People from commercial and international trade areas \\
\hline & \multirow{4}{*}{$\begin{array}{l}\text { Promotional } \\
\text { activities }\end{array}$} & Trade fairs and exhibitions \\
\hline & & Trade missions \\
\hline & & Events, meetings and collaborative workspaces \\
\hline & & Other promotional actions \\
\hline \multirow[t]{14}{*}{$\begin{array}{l}\text { External } \\
\text { sources }\end{array}$} & \multirow[t]{8}{*}{$\begin{array}{l}\text { Entities and } \\
\text { organizations }\end{array}$} & $\begin{array}{l}\text { National institutional entities (government, embassies, } \\
\text { federations, chambers of commerce, and other business } \\
\text { associations) }\end{array}$ \\
\hline & & $\begin{array}{l}\text { Foreign institutional entities (governments, embassies, } \\
\text { federations, chambers of commerce, and other business } \\
\text { associations) }\end{array}$ \\
\hline & & Consulting agencies \\
\hline & & Other companies (not members of the IBA) \\
\hline & & The press (e.g. press TV, journalists, news media) \\
\hline & & Overseas agents and distributors \\
\hline & & Universities and research institutes \\
\hline & & Banks \\
\hline & \multirow[t]{6}{*}{ Internet } & International market studies and surveys \\
\hline & & Statistics \\
\hline & & Websites \\
\hline & & Search engines \\
\hline & & Databases, directories and repositories \\
\hline & & On-line journals and newspapers \\
\hline
\end{tabular}


relevant information source. The associates express not only their needs to the IBAs but also indicate some specific countries that can be of interest for the exportations of the sector, or even some specific internationalization projects and opportunities. What they expect in return is for the IBA to use its contacts, services and knowledge base, and to act as intermediary between them and entities of interest. The use of databases are also mentioned by the interviewees, but only some of them are actually using this data source because it has high costs of acquisition. Some particular entities and organizations are also mentioned by the interviewees as being important sources of information about international trade and activities:

- International sources:

- European Commission; Horizon 2020; OECD (Organization for Economic Co-operation and Development); WTO (World Trade Organization); BusinessEurope (confederation of European business), nTrade (statistics).

- National sources:

- CIP (business confederation of Portugal), AICEP (external trade and investment agency of Portugal), INE (national institute of statistics), Republic Diary and Assembly of the Republic (for more legal information), IAPMEI (public agency for competitiveness and innovation), Bank of Portugal, and Portugal 2020 (a partnership agreement between Portugal and the European Commission that provides funding opportunities for the Portuguese business).

\section{Expert Opinion and Additional Information Sources}

Findings from the expert opinion allowed to identify additional international portals, databases, directories and repositories from specific entities and websites. These data and information sources can be accessed and used by IBAs to support SME internationalization. Table 3 presents only the ones that represent new information sources, not identified in the previous sections.

Table 3. Additional data and information sources identified with expert opinion

\begin{tabular}{l|l}
\hline Type of source & Information source \\
\hline \multirow{3}{*}{ External sources } & $\begin{array}{l}\text { FITA (Federation of International Trade } \\
\text { Associations) Global Trade Portal }\end{array}$ \\
\cline { 2 - 2 } & World Bank \\
\cline { 2 - 2 } & $\begin{array}{l}\text { WAIPA (World Association of Investment Promotion } \\
\text { Agencies) }\end{array}$ \\
\cline { 2 - 2 } & United Nations \\
\cline { 2 - 2 } & IMF (International Monetary Fund) \\
\cline { 2 - 2 } & ITC (International Trade Center) \\
\cline { 2 - 2 } & Enterprise Europe Network \\
\hline & Trade Map (International Trade Center) \\
\hline
\end{tabular}


Table 3. (continued)

\begin{tabular}{|c|c|}
\hline Type of source & Information source \\
\hline \multirow[t]{4}{*}{$\begin{array}{l}\text { Statistics of international } \\
\text { trade }\end{array}$} & $\begin{array}{l}\text { Comtrade (United Nations Commodity Trade Statistics } \\
\text { Database) }\end{array}$ \\
\hline & United Nations Data Retrieval System \\
\hline & Eurostat (European Commission) \\
\hline & OECD.Stat \\
\hline \multirow[t]{4}{*}{ Tariff and non-tariff barriers } & Market Access Map (International Trade Center) \\
\hline & WTO - Tariffs \\
\hline & The Market Access Database (European Commission) \\
\hline & I-TIP Goods (WTO) \\
\hline \multirow[t]{5}{*}{ Business directories } & Bureau Van Dijk \\
\hline & FITA Global Trade Portal \\
\hline & GlobalTrade.net \\
\hline & Kompass \\
\hline & Thomasnet \\
\hline \multirow{9}{*}{$\begin{array}{l}\text { Countries' reports, ratings } \\
\text { and indicators }\end{array}$} & Doing Business (World Bank) \\
\hline & $\begin{array}{l}\text { World Competitiveness Center (IMD business school for } \\
\text { management and leadership courses) }\end{array}$ \\
\hline & World Economic Forum \\
\hline & IPS (Institute for Industrial Policy Studies) \\
\hline & The Global Innovation Index \\
\hline & Economist Intelligence Unit (The Economist Group) \\
\hline & External Markets (AICEP) \\
\hline & Country Profiles and Resources (FITA) \\
\hline & Multilateral Investment Guarantee Agency (World Bank) \\
\hline \multirow[t]{8}{*}{ Sectorial reports } & Oxford Economics \\
\hline & Industry analysis (Economist Intelligence Unit) \\
\hline & Frost \& Sullivan \\
\hline & D\&B Hoovers \\
\hline & Plimsoll World \\
\hline & BMI Research \\
\hline & Datamonitor Healthcare (Pharma intelligence) \\
\hline & Euromonitor International \\
\hline \multirow[t]{2}{*}{ Portals } & SME internationalization portal (European Commission) \\
\hline & European Small Business Portal (European Commission) \\
\hline
\end{tabular}

\section{A Socio-Semantic Model of a Collaborative Network Mediated by a Digital Platform}

Previous research show that IBAs can have a more active role in supporting SME internationalization, by fostering more collaborations between associates [6]. This support can also be enhanced by improving their information management role to better 
meet companies' informational needs [8]. Therefore, one important development for the positive impact of IBAs on the internationalization process can be the evolution towards a more collaborative network, fostering flows of information between associates [7]. Consequently, by having in consideration these previous findings, and with the new findings described in this paper, it is a natural conclusion that an effective collaborative network, where one of the main goals is to share information and knowledge about internationalization processes, can be achieved by means of a digital platform which can mediates social relations, levered in data and information management.

Therefore, based on a socio-semantic perspective [10, 11], we present the conceptual skeleton of the IBA-SME digital platform (Fig. 1) modelling the users (SMEs) structural links through descriptive profiles (implementation of a social network), the basic information structure to organize information gathered from the internationalization information sources (semantic network), and the linkage between users and information (socio-semantic network).

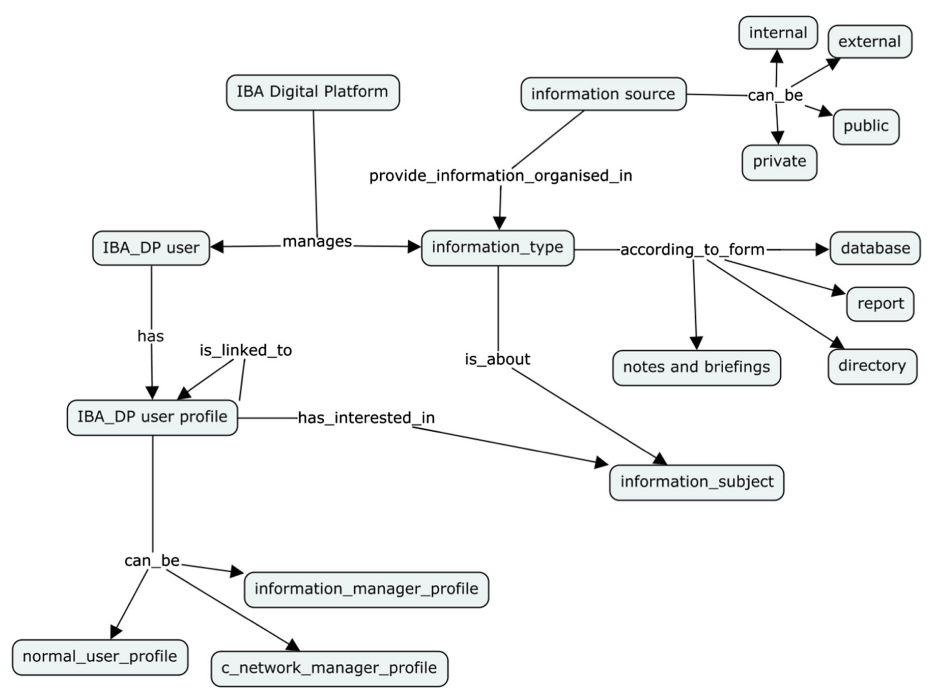

Fig. 1. Conceptual model of an IBA-SME digital platform

Figure 2 shows an instantiation of the conceptual model where the socio-semantic network becomes clear. A set of round shaped nodes representing the users (or, institutionally, the SMEs) are linked through is_linked_to named edges. This implements the usual social network connections.

The set of rectangle shaped nodes representing the information subjects are linked through is_a or is_type_of, is_part_of, or a general binary relationship. On its turn, this implements a semantic network. The dotted edges, labelled as has_interest_in, connect users with information subjects. From these links, a second social network can be derived connecting users through their common 


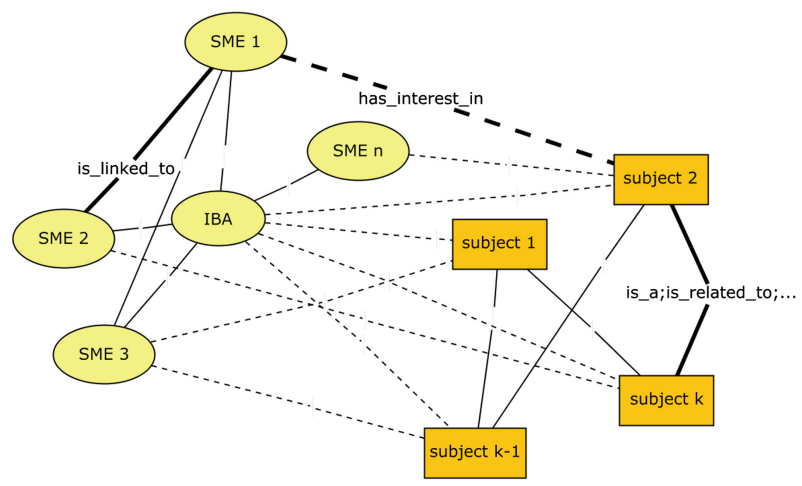

Fig. 2. Socio-semantic network model of a collaborative network mediated by the IBA-SME digital platform

information subject interests. The management of the IBA accumulates the roles of network manager and information manager (modelled by the respective profiles) implementing the usual Network Administrative Organization (NAO) governance type for this kind of organization [29].

This section presents a first instantiation of a socio-semantic model of a collaborative network for supporting SME internationalization, mediated by a digital platform and managed by IBAs. Naturally, this is only a small advance in terms of the modelling approach. Nevertheless, this first model serves as a basis for further developments for improving next stages of the information management life-cycle.

\section{Conclusion}

This study contributes for the development of IBAs as important information sources for the international activities of SMEs. The identification of data and information sources that can be useful for both improving the IBAs' support and the internationalization of SMEs, represents an important step for contributing to this IBAs' evolution. Future developments will be concentrated in further stages of the information lifecycle, by identifying specific information content and categories from the identified sources, by studying ways of organizing and storing this information, and by understanding the means and channels to be used for distributing this information.

In complementarity to this, the socio-semantic network model will progress and will evolve in the following ways: (i) by adding more detail on the relations and links between the social organizations (social network); (ii) by adding new concepts and domains, and their relations in terms of conceptual structures (semantic network); and (iii) by exploring the links between these previous networks (socio-semantic network).

Finally, this paper can also contribute to the broader community of Collaborative Networks, by showing the application of the socio-semantic approach developed by Pereira et al. $[10,11]$. Results of this study allow to support the arguments of these authors about using this approach for obtaining a more integrated view between knowledge 
structures and social structures, when analyzing collaborative networks of organizations. This opens avenues for other researchers to use and explore this approach in their collaborative network projects.

Acknowledgments. This research was funded by the Portuguese funding agency, Fundação para a Ciência e a Tecnologia (FCT), through the Ph.D. Studentship SFRH/BD/110131/2015. It was also supported by the Project "TEC4Growth - Pervasive Intelligence, Enhancers and Proofs of Concept with Industrial Impact/NORTE-01-0145-FEDER-000020" financed by the North Portugal Regional Operational Programme (NORTE 2020), under the PORTUGAL 2020 Partnership Agreement, and through the European Regional Development Fund (ERDF).

\section{References}

1. Smallwood, R.F.: Information Governance: Concepts, Strategies and Best Practices. Wiley Online Library, Hoboken (2014)

2. Knight, G., Liesch, P.: Information internalisation in internationalising the firm. J. Bus. Res. 55, 981-995 (2002)

3. Costa, E., Soares, A.L., Sousa, J.P.: Information, knowledge and collaboration management in the internationalisation of SMEs: a systematic literature review. Int. J. Inf. Manage. 36, 557-569 (2016)

4. Leonidou, L.C., Theodosiou, M.: The export marketing information system: an integration of the extant knowledge. J. World Bus. 39, 12-36 (2004)

5. Riddle, L.A., Gillespie, K.: Information sources for new ventures in the Turkish clothing export industry. Small Bus. Econ. 20, 105-120 (2003)

6. Costa, E., Soares, A.L., Sousa, J.P.: A new insight in the SMEs internationalization process. In: Camarinha-Matos, Luis M., Bénaben, F., Picard, W. (eds.) PRO-VE 2015. IAICT, vol. 463, pp. 398-410. Springer, Cham (2015). doi:10.1007/978-3-319-24141-8_36

7. Costa, E., Soares, A., Sousa, J., Jamil, G.: Information management for network transformation in industrial enterprises associations: the case of the internationalization process. In: Jamil, et al. (eds.) Handbook of Research on Information Management for Effective Logistics and Supply Chains, pp. 415-436. IGI Global, Hershey (2017)

8. Costa, E., Soares, A.L., Sousa, J.P.: Situating case studies within the design science research paradigm: an instantiation for collaborative networks. In: Afsarmanesh, H., Camarinha-Matos, Luis M., Lucas Soares, A. (eds.) PRO-VE 2016. IAICT, vol. 480, pp. 531-544. Springer, Cham (2016). doi:10.1007/978-3-319-45390-3_45

9. Detlor, B.: Information management. Int. J. Inf. Manage. 30, 103-108 (2010)

10. Pereira, C., Sousa, C., Lucas Soares, A.: A socio-semantic approach to collaborative domain conceptualization. In: Meersman, R., Herrero, P., Dillon, T. (eds.) OTM 2009. LNCS, vol. 5872, pp. 524-533. Springer, Heidelberg (2009). doi:10.1007/978-3-642-05290-3_66

11. Pereira, C., Sousa, C., Soares, A.L.: Supporting conceptualisation processes in collaborative networks: a case study on an R \& D project. Int. J. Comput. Integr. Manuf. 26, 1066-1086 (2013)

12. Nguyen, T., Barrett, N., Fletcher, R.: Information internalisation and internationalisation: evidence from Vietnamese firms. Int. Bus. Rev. 15, 682-701 (2006)

13. Theodosiou, M., Katsikea, E.: The export information system: an empirical investigation of its antecedents and performance outcomes. J. Int. Mark. 21, 72-94 (2013)

14. Xie, Y., Amine, L.: Social networks and the internationalization of Chinese entrepreneurs. Glob. Bus. Organ. Excell. 29, 61-78 (2009) 
15. Akerman, N.: An international learning typology: strategies and outcomes for internationalizing firms. Balt. J. Manag. 9, 382-402 (2014)

16. Bartosik-Purgat, M., Schroeder, J.: Polish exporters' use and perception of various sources of market information. Poznań Univ. Econ. Rev. 14, 97-117 (2014)

17. Leonidou, L.C., Katsikeas, C.S.: Export information sources: the role of organizational and internationalization influences. J. Strateg. Mark. 5, 65-87 (1997)

18. Benito, G.R.G., Solberg, C.A., Welch, L.S.: An exploration of the information behaviour of Norwegian exporters. Int. J. Inf. Manage. 13, 274-286 (1993)

19. Leonidou, L.C.: Types and sources of export information: insights from small business. Int. Small Bus. J. 17, 30-48 (1999)

20. Walters, P.: International market information infusion: data acquisition behaviour in Norwegian exporters. Int. J. Inf. Manage. 16, 437-444 (1996)

21. Walters, P.G.P.: Export information sources: A study of their usage and utility. Int. Mark. Rev. 1, 34-43 (1993)

22. Danik, L.: Information Sources applied in search for a foreign business partner and the perception of barriers in establishing international cooperation. In: Ann. Univ. Mariae Curie-Sklodowska, vol. XLIX, pp. 39-48 (2015)

23. Nguyen, T.D., Barrett, N.J.: The adoption of the internet by export firms in transitional markets. Asia Pacific J. Mark. Logist. 18, 29-42 (2006)

24. Bennett, R.: Business associations and their potential contribution to the competitiveness of SMEs. Entrep. Reg. Dev. 10, 243-260 (1998)

25. Traxler, F., Huemer, G.: Handbook of Business Interest Associations, Firm Size and Governance: A Comparative Analytical Approach. Routledge, London (2007)

26. Boléat, M.: Managing Trade Associations. Trade Association Forum, London (2003)

27. Gashi, P., Hashi, I., Pugh, G.: Export behaviour of SMEs in transition countries. Small Bus. Econ. 42, 407-435 (2013)

28. Patel-Campillo, A., DeLessio-Parson, A.: Why types of operations, trade associations, and production trends matter in the geographic branding of an emerging industry. J. Wine Res. 27, 242-256 (2016)

29. Provan, K., Kenis, P.: Modes of network governance: structure, management, and effectiveness. J. Public Adm. Res. Theory 18, 229-252 (2008) 